\title{
Identity in Difference: Substance and Nature in Leontius of Byzantium's Writings
}

\author{
Timur Shchukin \\ National Research University Higher School of Economics, Russia \\ tim_ibif@mail.ru
}

\begin{abstract}
Dirk Krausmüller believes that Leontius of Byzantium in the first book of his early treatise Contra Nestorianos et Eutychianos supposes the singularity to include three elements: (1) unqualified substrate, (2) set of substantial idioms, and (3) set of hypostatic idioms. In my opinion, this structure looks a little different: (1) substance, which represents the universal without substantial and para-substantial features, (2) nature, which contemplated only with these features and (3) hypostasis. The different usage of the terms "substance" and "nature," as well as the expressions like "communication by nature" and "junction by substance," which have a completely distinct meaning, serves as a proof of this basically thesis. Nevertheless, the descriptive model of Contra Nestorianos et Eutychianos has been somewhat modified in a later treatise Solutio. Leontius of Byzantium suggests that the singularity should include (1) nature or substance in the meaning of species, (2) individual nature, which, besides the natural qualities, includes also the hypostatic ones, (3) hypostasis itself rendering being to the whole described construction. This transformation has been done due to different polemical purposes (?). Leontius of Byzantium tries to justify not the common character of nature, but the way the common nature takes being in the singularity.
\end{abstract}

\section{Keywords}

Christology - nature and substance - Leontius of Byzantium - Neochalcedonism

* The present study is a part of a larger project № 16-18-10202, "History of the Logical and Philosophical Ideas in Byzantine Philosophy and Theology," implemented with a financial support of the Russian Science Foundation. 


\section{The Krausmüller's System and Its Shortcomings}

In his very important article, Dirk Krausmüller ${ }^{1}$ represents Leontius of Byzantium as a creator of a new doctrine on "mechanism" of common human nature individuation in the hypostasis of Jesus Christ. The theologian, according to him, in the first book of his early treatise "Contra Nestorianos et Eutychianos" ( $C N E$ I) supposes the singularity to include the three elements: (1) unqualified substrate, which Krausmüller identifies with what Leontius of Byzantium used to call "enhypostaton" (2) set of substantial idioms, which, while being combined with the unqualified substrate, constitutes "being," substance or nature, shapes the universal in the sense of possibility to exist in manifold of things as species, and (3) set of hypostatic idioms, that characterizes it as an individual, i.e. shapes the hypostasis and constitutes it. Krausmüller believes that this model has been formulated under the influence of Aristotelian logic, where the first substance acts as a carrier of substantial and para-substantial features, which don't exist beyond the first substance. Leontius of Byzantium, says the researcher, has complicated the Aristotelian model: his "enhypostaton" correlates with the "authypostaton" of Aristotle like substance and substantial idioms, separated from it, and it is "clearer" or more profound form of individual being than the first substance.

After the Krausmüller's research, one could confidently say that the threepart model of individuation, described by Richard Cross for "Solutio argumentorum a Severe objectorum" (Solutio), ${ }^{2}$ is completely present already in $C N E \mathrm{I}$, and thus, comparatively to $C N E$ I, Solutio represents not a radically new doctrine, but just a specification, the necessity whereof has been determined by the polemics with Monophysites (or those thinking Monophysite-like within the Chalcedonite party). However, in my opinion, there are two problematic points in Krausmüller's conception, which, nevertheless, concern not its very structure, but characteristics of its elements.

1 D. Krausmüller, "Making Sense of the Formula of Chalcedon: the Cappadocians and Aristotle in Leontius of Byzantium's Contra Nestorianos et Eutychianos," vc, 65 (2011), pp. 484-513.

2 R. Cross names "individual natures" what Leontius of Byzantium opposes to the partial natures according to Monophysites: "An individual nature is a universal nature considered along with a (unique) collection of universal accidents. (Contrast the case of particular natures, which are the instances of a universal in abstraction from their accidents)" (R. Cross, "Individual Natures in the Christology of Leontius of Byzantium," JECs, 10 (2002), p. 252). Thus, from Cross' point of view, Leontius sorts out three components of the hypostasis: (1) common nature, (2) individual nature, (3) being as hypostasis. 
First, the researcher underlines that an unqualified substrate is what "complements common nature in concrete beings and gives it reality,"3 i.e. the common nature in pure form is transferred beyond the being-in-singularity and may be present in it only owing to the unqualified substrate. To my mind, it is a disputable assertion. In the first turn, there are no explicitly characteristics of the "enhypostaton" as a partial reality in $C N E \mathrm{I}$, and the issue is rather more about the full opposition to the final stage of individuation, i.e. singularity or hypostasis. I'll quote the phrase Krausmüller basically refers to:

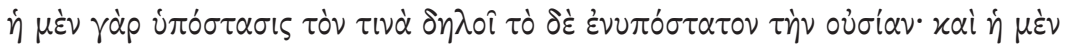

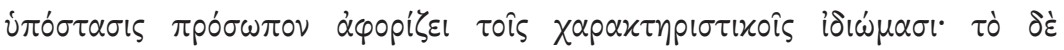

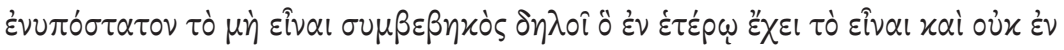

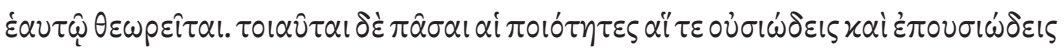

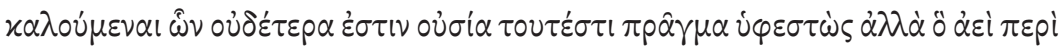

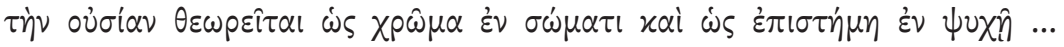

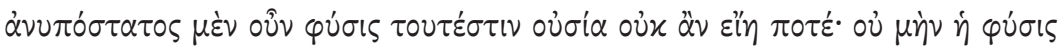

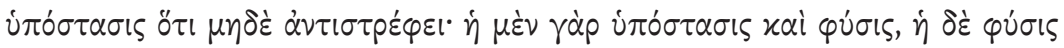

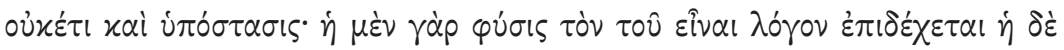

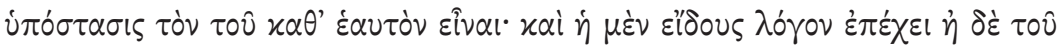

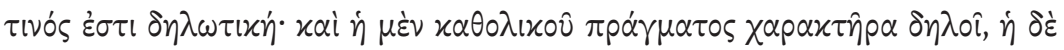

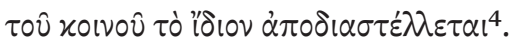

... the hypostasis indicates the singularity, while the enhypostaton indicates the substance. The hypostasis defines the person by characteristic idioms, whereas the enhypostaton demonstrates that it is not an accidental having its being in the other, and it is not contemplated in itself. Such are all qualities, those that are named substantial and para-substantial, wherefrom none is a substance, i.e. real thing, but is always contemplated near the substance, like color in the body or knowledge in the soul .... A nature or substance, which is anhypostatos, will never exist, but nature is not hypostasis because the argument is not reversible: hypostasis is also nature but nature is not yet also hypostasis. For nature takes the logos of being whereas hypostasis also takes the logos of self-reliant being. The nature has a sense of species, while the hypostasis demonstrates singularity. The nature exposes the character of the general thing and the hypostasis separates the proper from the common.

3 Krausmüller, "Making Sense of the Formula of Chalcedon," p. 484.

4 Leontius of Byzantium, $C N E$ I, in $P G$ 86a, col. ${ }_{1277} \mathrm{C}-1280 \mathrm{~A}$. 
The enhypostaton responds to the substance the same way as the singularity to the hypostasis. And just as the hypostasis completes the individuation through adjoining the characteristic idioms to substance, the enhypostaton "rejects" what constitutes not only individuality but also definition and providing quality to the nature.

If, second, according to the Krausmüller's reconstruction, the nature or the substance by Leontius of Byzantium appear as something common and is characterized by substantial idioms, it should be logical to suggest that when they devoid of the latter, the former would correspond to the reality more common than themselves. Therefore, all the "individuality" of the unqualified substrate would consist in the necessity of being-in-singularity. In this case, the unqualified substrate will correlate not to the deeper level of Aristotle's first substance, but to his second substance, abstracted from substantial and parasubstantial qualities. In Solutio, Leontius of Byzantium identifies the "naked" nature or species with the nature already complemented by the accidentals. ${ }^{5}$ By that, within the framework of Leontius' logic it is totally incorrect to speak of individuality existing beyond the real being in the hypostasis: the common nature retains its self-identity regardless of whether it is joined with the accidentals or not. Eo ipso, the enhypostaton might be interpreted only as one of the modes of being for the self-identical common nature.

The second problematic point is identifying the hypostatic being and the set of hypostatic idioms. In the excerpt quoted above, ${ }^{6}$ they correlate with the hypostasis the same way as the substantial and para-substantial qualities do with the substance (as well as with the enhypostaton), and, it might be possible, while the substance possesses the being, which is not reduced to the qualities, the hypostasis likewise has that not reduced to the hypostatic idioms and, therefore, arises not only due to conjoining them. This is indicated also by the definition of hypostasis given below:

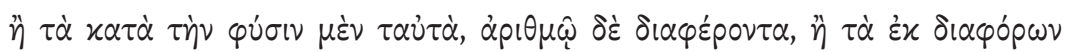

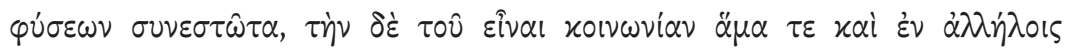
$\varkappa \varepsilon \varkappa \tau \eta \mu \varepsilon ́ v \alpha$

... this is either what is identical by nature but differs by number; or what consists of different natures but has communion of natures within each other in its existence. ${ }^{7}$

\footnotetext{
5 Leontius of Byzantium, Solutio, in $P G$ 86b, col. 1917B9-10.

6 Leontius of Byzantium, $C N E$ I, in $P G$ 86a, col. ${ }_{1277} \mathrm{C}-1280 \mathrm{~A}$.

7 Ibid., col. 1280A10-B1.
} 
In this definition, the characteristic idioms don't play any role at all, so the hypostasis' key feature becomes the pure otherness to the other hypostasis. Indeed, the hypostasis becomes hypostasis owing to the "logos of self-reliant being." In $C N E$ I, nevertheless, it is not given with enough clearness, and the "logos of self-reliant being" is not explicitly described as something different from the set of hypostatic idioms. On the other hand, it's been performed in Solutio, where Leontius of Byzantium first oppose the partial nature, identical to species, to the hypostasis, and then exposes how does it work in Christology, where personal features of Jesus Christ just separate him from other human individuals, while he accepts the hypostatic being in the hypostasis of the Word. ${ }^{9}$

Because the very idea of multilevel individuation seems right to me, with just certain elements to be appreciated in a wrong way, I would propose a somewhat different scheme, which, for the case of $C N E \mathrm{I}$, is based on a distinction between the notions of substance and nature.

\section{Substance and Nature}

Leontius of Byzantium, with all reservations, tries to use the terminological system of Cappadocian triadological theology for the Christology and rejects the Monophysite-promulgated thesis on that a new substantial reality requires new terminology. The thinker insists on the universal range of terminology. ${ }^{10}$

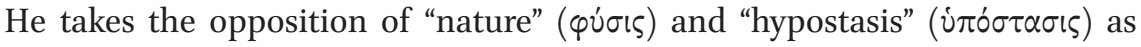

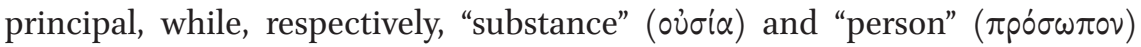
serve as doublets to them. This is what he declares in the very beginning of $C N E$ $\mathrm{I}^{11}$ and says repeatedly further. ${ }^{12}$

It, however, should not be ignored that in Leontius' texts a non-synonymic usage of these notions can be discovered. Even the initial pages of $C N E$ I point at that:

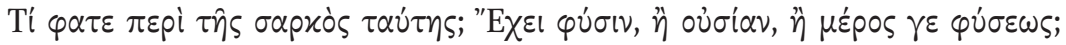

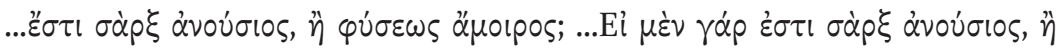

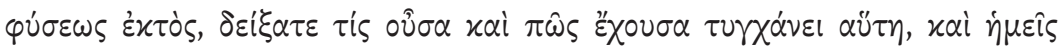

\footnotetext{
8 Ibid., col. $1280 \mathrm{~A}_{7}$.

9 Leontius of Byzantium, Solutio, in PG 86b, col. 1917CD.

$10 \quad$ Ibid., col. 1921D1-1924A6.

11 Leontius of Byzantium, $C N E$ I, in $P G$ 86a, col. 1273A5-8.

12 Ibid., col. 1277B4-6; 1280A1-2; 1305C9-11.
} 


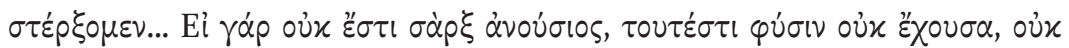

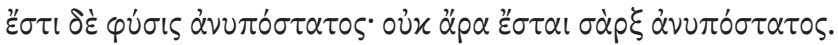

What would you say about this flesh [of Christ]? Does it possess substance, or nature, or part of nature? ... Is there a flesh not possessing substance or having no part in the nature? ... If a flesh exists, which has no substance or staying beyond the nature, let you show if it exists while being anything and in any mode, and we'll be satisfied .... So, once there's no flesh devoid of substance, that is, not having nature, and also there's no nature which is not enhypostaton, so, therefore, there'll be no enhypostaton flesh either. ${ }^{13}$

In this excerpt, "substance" and "nature" are evidently utilized in an utterly congenial sense, but they are not synonyms. It could be supposed that their distinction has been stipulated by polemical purposes of the treatise and that it's been actual for those the treatise confronts to. Indeed, in Severus of Antioch's logical system, the distinction between the substance and the nature played a prominent part: as different from Julianus of Halicarnassus, he thought that "the deity of the only-begotten Word and the humanity, which is hypostatically joined with him, are not the same substance," and that "upon the unification a difference between the deity and the humanity remains that two natures has been combined into one nature ... however, with the difference in the substance, keeping the quality features." ${ }^{14}$ The substance in Severus' system perfectly corresponds to the Aristotle's second substance, which means that it is the common reality, the species, which is present in every singularity of the species. Meanwhile, the nature is an individuality specified within this species, but having not accepted the hypostatic (real) being. The substance and the nature are not identical.

For certain, such logic was unacceptable for Leontius of Byzantine. And it is a fact that the substance and the nature are identical for him in respect of that participating them means participation in the being. ${ }^{15}$ Both substance and nature have purely logical dimension while being represented as universals. ${ }^{16}$ Both substance and nature accept being only in an individual. And since there is no substance and nature beyond the individual, there's no substance and

\footnotetext{
13 Ibid., col. 1277АB.

14 Severus of Antioch, Adversus Apologiam Iuliani, 21, in: Severe d'Antioche, La polémique antijulianiste, éd. R. Hespel, II B (Csco, 301-302; Syr 126-127), Louvain, 1969, pp. 292/256257 (txt/tr.)

15 Leontius of Byzantium, CNE I, in PG 86a, col. 1277A14-B1.

16 Ibid., col. 1292A3-6; cf. col. 128oA7-10.
} 
nature without qualities, which allow the substance and the nature be represented as a universal. ${ }^{17}$ Leontius of Byzantine unambiguously speaks about substance and nature as common realities. Nevertheless, it's worthy to suggest that their distinction has been thought namely within the paradigm "from the unconditionally common to the individualized common."

The difference between the substance and the nature is connected with how do they relate to the qualities. Leontius of Byzantium focuses on that the substance, notwithstanding that it cannot be speculated without qualities, has, however, a being independent from them: "qualities ... are named substantial and para-substantial, wherefrom none is a substance, i.e. real thing, but is always contemplated near the substance, like color in the body or knowledge in the soul."18 I am disposed to agree with Krausmüller in that the nature is a carrier of the set of substantial idioms. Actually, Leontius points at the fact that the nature differs from the hypostasis only in that it has no "logos of self-reliant being," and, consequently, it always has substantial idioms in itself. ${ }^{19}$

Thus, within the framework of Leontius' logical system, the nature possesses everything which is proper to the individual, except for being an individual, but that shouldn't be said about the substance (in the meaning of common), i.e. Leontius doesn't distinguish the nature and natural features, whereas he does that for the substance and its qualities, substantial and para-substantial. By that, provided that the substance and the nature are speculative being having no existence different from real, and therefore they are considered logically as common for the singularity, they are identical, and it is what Leontius insists on. They differ not as themselves, but in regard of what individualizes them: the "substance" is the being of the thing prior to its quality definitions, whereas the "nature" is what is taken together with these definitions.

\section{Communication by Nature and Junction by Substance}

The brightest illustration of the fact that Leontius considers the substance and the nature non-identical, is the co-existence of expressions like "communica-

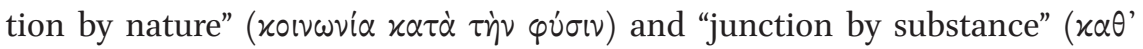

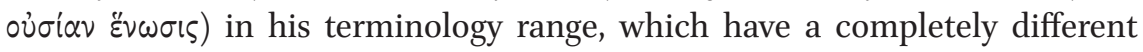
meaning.

The "communication by nature", proper to individuals regarding the species, is opposed by Leontius of Byzantium to the "communication by naming"

\footnotetext{
17 Ibid., col. 128oB1-4.

18 Ibid., col. 1277 D7-11.

19 Ibid., col. 128oA3-7.
} 
( of partial things, ${ }^{20}$ i.e. the "communication by nature" has a connotation of the real communication, expressed in implementation of the substantial idioms within the singularity, which differs from the nominal communication. Alongside that, Leontius offers three possibilities of when we can speak of natural

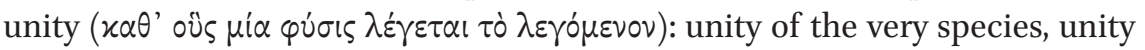
of the individuals within the species and unity of realities belonging to other species, which represents the tertium quid, a certain third. ${ }^{21}$ It could be supposed that $\mu$ í $\varphi \dot{v} \sigma \varsigma$ in the sense of unity of the species is a pure logical abstraction, but it contradicts to the aforementioned general definition of nature ${ }^{22}$ and it does not implicate abstracting the nature out of substantial idioms, and,

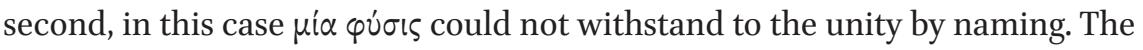
participation in the nature, thus, always implicates either potential or actual distribution of substantial idioms by singularities and never points at the abstract general.

When saying "by substance, via substantial and enhypostatic junction" ( $\dot{\eta}$

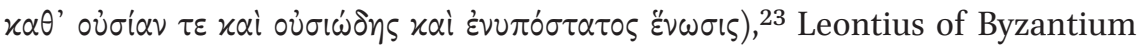
nominates the junction of divine and human natures in Jesus Christ, which as itself means that the substance isn't fully identical to what comes into immediate contact.

However, the "junction by substance" is not an obligatory junction resulting in that natures (quality specificity) does not modify their being, though it is namely this kind of junction that Leontius considers appropriate to the incarnation of God:

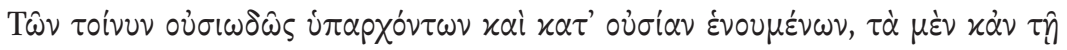

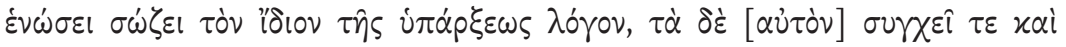

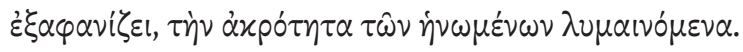

... out of what exists substantially and joins by substance, one retains its special logos of existence even in junction, while the other mingles it and utterly destructs it, so that the extreme features of those being unified are eliminated. ${ }^{24}$

\footnotetext{
20 Ibid., col. 1289D12-1292A2.

21 Ibid., col. 1292BC.

22 Ibid., col. 1280A $7-10$.

23 Ibid., col. 1300A9-10; in the same sense he seemingly affirms that the Word has been uni-

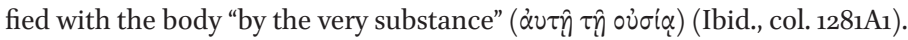

Leontius of Byzantium, CNE I, in PG 86a, col. 1304B1-4.
} 
In $C N E \mathrm{I}$, the "junction by substance" is distinguished from junction "by action"

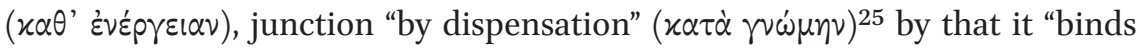

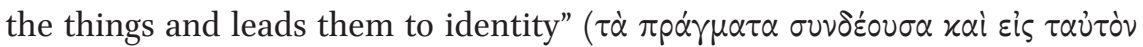
$\alpha \gamma \gamma \sigma \sigma \alpha) .{ }^{26}$ By that, the function of the substance is in shaping a connection between things prior to communicating them any concrete proprieties. The connection, nonetheless, shouldn't be whatsoever, but only that communicates the identity to the things, which means definitiveness to the being-insingularity, the identity in general, once more, so far devoid of the quality definitions.

Leontius of Byzantium supposes that any junction, which distincts from that by substance, is not a "junction of things," but a "junction of dignity" (o

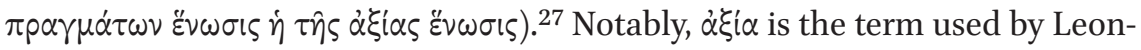
tius' opponents, Nestorians ${ }^{28}$ or, according to David Evans, ${ }^{29}$ representatives of one of Origenistic parties, who "amalgamate the dignities into one dignity and

25 Ibid., col. 1297 $44-5$; cf. col. 130oB12.

26 Ibid., col. $1300 \mathrm{C}_{5}-7$.

27 Ibid., col. 1300 D1.

28 See "Prior to incarnation, God the Word had been Son and God, co-existing with the Father, but in the last times accepted the image of slave. Nevertheless, being and being called Son before that, he, upon the acceptance, could not be called divided Son, so that we wouldn't affirm two Sons as a dogma. And since the junction takes place with this initial being, which is adjoined to the very [humankind] by Son, it is impossible to accept the division according to the dignity of Sonship. I emphasize, by the dignity of Sonship,

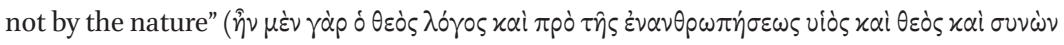

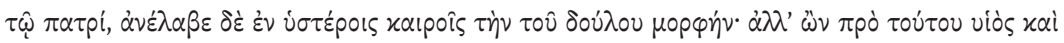

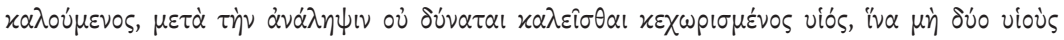

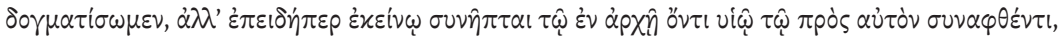

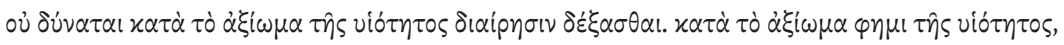

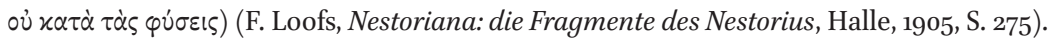

29 In $C N E$ I, in a passage containing critics of the conception of junction "by dignity" (CNE I, in $P G$ 86a, col. 1300B13-1301C12) Leontius of Byzantium, in the researcher's opinion, is polemicizing, inter alia, with the Christology of Dionysius Areopagites, recounted in $D N$ II, 6, as well as in Ep. ІІІ и IV. These texts, Evans supposes, were important for Origenists, because the conception of pre-existing Christ conciliated the author of the corpus with Euagrius of Pont. However, Evans reminds that Palestinian Origenists didn't hold the unity in their rows: those more radical ("isochristai") believed that upon the resurrection the minds of righteous men will be equal to Christ, whereas the "protoctistai" thought Christ to ontologically prevail over the other souls and all the things created, being a result of the first creation. Because eo ipso he eventually becomes the fourth hypostasis, the protoctistai were also called "tetraditai" (cf. A. Grillmeier, Christ in Christian Tradition, Vol. 2/3, New York, 2013, p. 8o). According to Evans, Leontius of Byzantium belonged to the protoctistai, while having had the Origenists-isochristai as opponents, right over their 


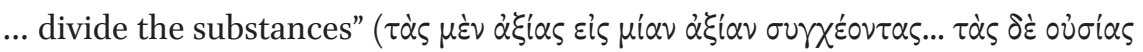
$\left.\chi \omega p^{\prime} \zeta o v \tau \alpha \varsigma\right),{ }^{30}$ i.e., on the one hand, they assert that the things are able to come to unity once with quality specificity, and at the same time belong to different species. However, the logical system of Leontius postulates this notion to signify any form of reality and apartness of things, which, when combined with the thing of other substance or nature (they are synonymic in this context), is not able to retain its identity, but transforms into tertium quid. For the junction of dignities supposes also that of natures, id est, a set of qualities standing behind them, while upon the junction (1) both natures and dignities are mingled, (2) and the degree of mixture is inversely proportional to the difference in dignity, ${ }^{31}$ so the more self-sufficiency the thing accepts before the junction, the more disastrous would be the result of junction and it will be destroyed. Thus, the "junction of dignities" is not a junction of things in the sense that it does not allow the quality specificity to be kept upon the junction. Leontius reasonably notes that in the opposite case, once the quality specifities had been included into the "new" thing, this junction would have been nothing different from junction with God of any other saint. Each saint, then, should have been confessed identical with the divine substance, but having two natures. ${ }^{32}$ That means, on the one hand, the mixture of dignities would have led to mixture of substances (it's not quite obvious why does Leontius call a newly created substance divine), but quality specificity of each saint wouldn't have mingled with that of the Word.

Grillmeier suggests that "junction by substance" is that "from 'essence' to 'essence', without mediation of the spiritual or corporeal potencies, as these would be proper to the divinity and humanity respectively (thus not through knowledge, will or senses), but through the koinonia of the substances." ${ }^{33}$ At my side, I would amplify this definition. In my opinion, the "junction by substance" is the kind of junction, where the substance accepts its definition only together with acceptance of hypostatic being, but in no case prior to it. Hence, if the unity of nature means the unity of universal, i.e. qualitatively defined general, the substantial unity implicates the junction of realities abstracted from qualities and accepting quality in the hypostasis.

\footnotetext{
leaning on Dyonisius Areopagites (D. Evans, "Leontius of Byzantium and Dionysius the Areopagite," Byzantine Studies, 7 (1980), pp. 1-34).

30 Leontius of Byzantium, CNE I, in PG 86a, col. 1300C11-13.

$31 \quad$ Ibid., col. 1300D4-10.

32 Ibid., col. 1300D1-4.

33 A. Grillmeier, T. Hainthaler, Christ in Christian Tradition, Vol. 2/2, London - Louisville, KY, 1995, p. 209.
} 


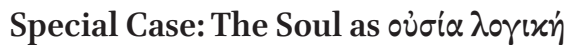

A special case of using the term ov $\sigma i \alpha$ is applying it to the soul. For example, it is referred to this way: "all reasonable substances may augment and lessen in

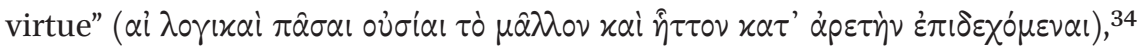
though the becoming and spatial and temporal features don't define the thing, i.e. don't relate to its substance. ${ }^{35} \mathrm{~A}$ soul itself could be called substance, ${ }^{36}$ as well as its reasonable part in opposite to this or other quality, for instance, incorporeity. ${ }^{37}$

One could suggest that here the talk is about a sort of philosophical bilinguism for Leontius of Byzantium. For, as cardinal Grillmeier has exposed, Leontius suits a neo-platonist Porphyrius in terminological shaping of this model, although probably not directly but via Nemesius of Emessa. ${ }^{38}$ In particular, it is from the Ancient thinker that he loans the basic definitions of soul, such as

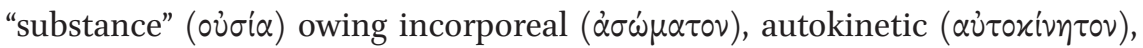
deathless ( $\dot{\alpha} \theta \dot{\alpha} v \alpha \tau o v)$ and imperishable ( $\dot{\alpha} v \dot{\omega} \lambda \varepsilon \theta \rho o v)$ being, ${ }^{39}$ which, notably, possesses it also after joining the body, "for neither in that, nor in this [sub-

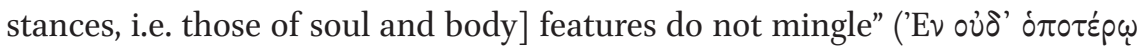

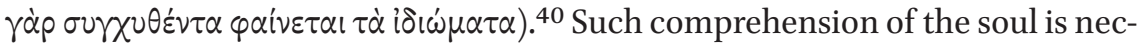
essary for Leontius in order to demonstrate the inalterability of the Word and human nature after the junction.

On the other hand, within the logic I propose, the soul, just like any other substance, is not contemplated beyond the natural and hypostatic definitions, but possesses the being, which is independent from those. It is an Aristotle-era interpretation of the soul:

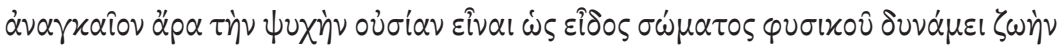

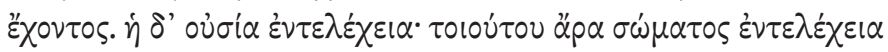

34 Leontius of Byzantium, $C N E$ I, in $P G$ 86a, col. 1284A4-6.

35 Ibid., col. $1281 \mathrm{D}_{4}-8$.

36 Ibid., col. 1281 Bg.

37 Ibid., col. 1296C10.

38 A. Grillmeier "Die anthropologisch-christologische Sprache des Leontius von Byzanz und

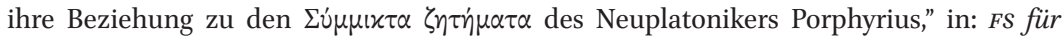
Hadwig Hörner zum 6o. Geburtstag, hg. von H. Eisenberger, Heidelberg, 1990, ss. 61-72.

39 Leontius of Byzantium, $C N E$ I, in $P G$ 86a, col. 1281B9-10.

40 Ibid., col. 1281A4-5. 
the soul is necessarily a substance in the sense of form of natural body, potentially possessing life. While the substance is an entelechy; therefore, the soul is the entelechy of such body. ${ }^{41}$

It's another matter that Leontius applies an aristotelian notion as already enriched by platonic and possibly Origenistic ${ }^{42}$ connotations.

\section{Refinement of Position: Partial Substance of Solutio}

The position Leontius gives out in later treatise Solutio is that in the hypostasis of the Word, the common natures of deity and humanity have come to unity, individualized via distinctive characteristics:

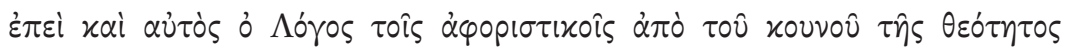

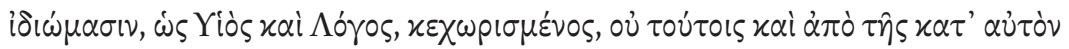

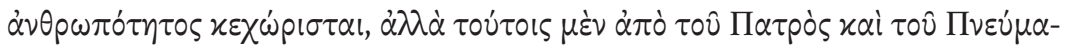

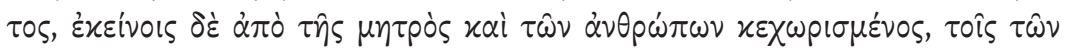

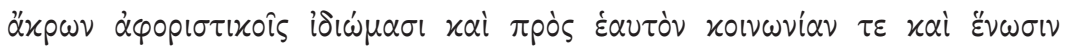

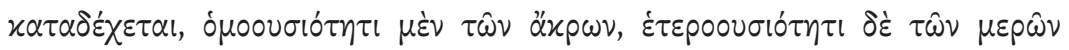

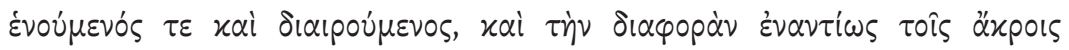

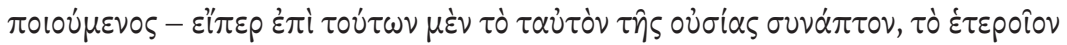

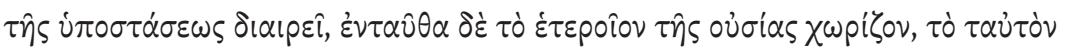

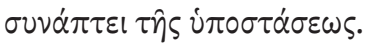

The Word itself has been distinguished by definitory features from the common deity, as Son and Word, not by those whereby it has separated itself from the humanity itself, but by ones from Father and Holy Spirit and by others from Mother and humans. With the help of definitory traits of extreme natures, he accepts communication and junction with himself, being unified and differing by consubstantiality of extreme natures and alter-substantiality of the parts, while creating a difference on the contrary by the extreme natures. Indeed, the identity of substance unifies in them and otherness of hypostasis divides. Because of this, the otherness of substance divides and the identity of hypostasis unifies. ${ }^{43}$

\footnotetext{
41 Aristotle, De an., 412a 20-24.

42 D. Krausmüller "Origenism in the Sixth Century: Leontius of Byzantium on the Pre-Existence of the Soul," Journal for Late Antique Religion and Culture, 8 (2014), pp. 46-67.

43 Leontius of Byzantium, Solutio, in PG 86b, col. 1917C9-D9.
} 
The theologian affirms that Christ, by his hypostatic features, which are common to many things, and belonging to the nature as well as to the hypostasis, ${ }^{44}$ differs from both Father and his Mother along with other human beings. By the junction, each of the natures retains these distinctive traits, due to which a unity becomes possible, wherein the individualized nature, first, accepts real being in the hypostasis of Jesus Christ, and, second, becomes consubstantial with other individuals of this very generality.

It is evident, then, that I find another terminological range, other comparatively to $C N E$ I: (1) nature or substance in the meaning of species, a universal, which, in this context, doesn't split into "pure" (substance) and qualified (nature), (2) individual nature, which, besides the natural qualities, includes also those hypostatic, (3) the hypostasis itself rendering being to the whole described construction. One can easily see that in this case Leontius has no need to distinct substance and nature. The nature owns the same features ( $\tau \dot{\alpha} \tau \dot{\eta} \nu$

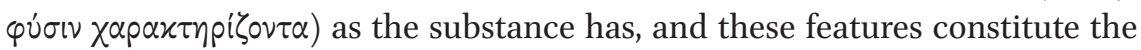
substance. ${ }^{45}$

In $C N E$ I (the fact Krausmüller has paid attention to) a distinction has been required of unqualified substrate and qualified nature. This, in particular, has furthered the critics of Monophysite doctrine on that divine and human features of the hypostasis of Jesus Christ aren't distributed by natures, that is, their duality doesn't lead to the duality of natures ${ }^{46}$ and therefore, the partial human nature, entering into the junction, is thought, in its turn, independently of its features. Leontius insists that the qualities are "tied" to the nature and for the reason that it is not partial but common, while being qualified, it represents itself as a universal for singularity. The specifics of Solutio in comparison with $C N E \mathrm{I}$ is in that here Leontius of Byzantium has a need to ground not the common character of the nature in opposite to the individual nature according to Monophysites and the hypostasis according to Nestorians having independent being, but, contrary to that, a specific (different from monophysitic)

44 See "... in the case of white and whitened, the things containing whiteness are both one

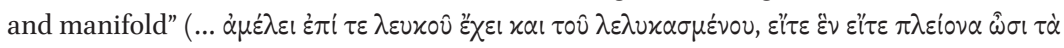

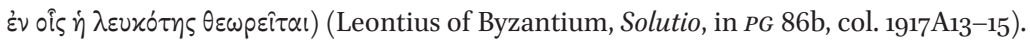
Leontius of Byzantium, Solutio, in PG 86b, col. $1945^{B} 3^{-4}$

46 See "We are also obliged to recognize the features of natures, where from Emmanuel takes origin. We call them particularities. It is what includes in the difference of natural quality ... but not what includes in the independent parts, which results in implicating the natures with independent existence" (Severus of Antioch, Epistula 1 ad Sergium, in: Seueri Antiocheni orationes ad Nephalium, eiusdem ac Sergii Grammatici epistulae mutuae, ed. J. Lebon (CSCO, 119), Louvain, 1949, p. 59). 
individuality of the natures that entered into the junction within the hypostasis of Jesus Christ. Owing to this, he had to make an accent not on the correlation between the "pure" species and its qualified form, but on that between the qualified nature that is a universal and, moreover, a universal combined with the hypostatic features. 